Review article

\title{
A Review of piggery manure management: generally, across western, Asian and African countries
}

\author{
J.B. Machete* and R.G. Chabo \\ Department of Animal Science and Production, Botswana University of Agriculture and Natural Resources, Private Bag \\ 0027, Gaborone, Botswana
}

\section{ARTICLE INFORMATION}

\section{Keywords}

Environmental impact

Legislation

Manure management systems

Piggery waste

Waste treatment system

\section{Article History:}

Submission date: 01 Apr. 2019

Revised: $\quad 17$ Jan. 2020

Accepted: 27 Jan. 2020

Available online: 04 Apr. 2020

https://bojaas.buan.ac.bw

\section{Corresponding Author:}

J.B. Machete

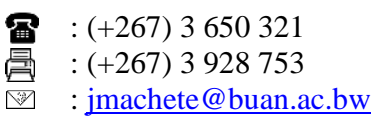

Abstract: The aim of this paper was to review the piggery waste management aspects in several countries of the world. Intensive livestock production produces significant quantities of waste that must be managed to protect water, air, and crop quality. The high demand of modern animal production has been influenced by the rapid growing populations as a result of rapid economic growth and increase in community living standards which is associated with the accelerated generation rate of solid waste causing a serious worldwide challenge. Piggery waste is said to be one of the most important causative agents of environmental pollution in most parts of the world. A growing pig population is unavoidable because it is a convenient source of protein to the growing human population and at the same time this means increasing piggery waste. Animal manure can provide nutrients for crops and fish production and input for biogas production, but if not managed, then this can also have a negative impact on the environment. Nevertheless, there are few countries who are considering legislation in relation to manure management.

\section{Introduction}

Livestock is very important in contributing to the sustainability of agricultural systems as an integral part of traditional farming system by using crop residues and other feeds which are not utilized by humans and converting them into milk and meat (Martinez et al, 2009). Manure from different livestock species can replace a good amount of mineral fertilizer as plant nutrients, provided it is recognized and used accordingly as a valuable resource (Bouwman and Booij, 1998; Chau, 1998). However, at the same time animal manure can be a source of air pollution as well as a threat to aquifers and surface water (Burton and Turner, 2003). Commercial pig production is rapidly growing in most parts of the world with a trend towards larger production units utilizing modern production technologies such as modern housing, improved feeding and better breeding methods. This type of trends influences the risk of water pollution, air pollution as well as soil pollution (Gerber et al. 2005)

\section{Pig Production and the Future}

Pig meat is the most consumed meat in the world (Gentry et al. 2002). It was noted that pork is the highest consumed protein with a total of 110 million metric tonnes followed by chicken with 104 million metric tonnes and beef with only 67 million metric tonnes per year (McGlone, 2013). China produced 50 million metric tonnes which is almost half of the world production in 2011 (Table 1). Germany was 
ranked the third pork producer (5 million metric tonnes) which is half of USA's pork production (McGlone, 2013). Asia, European Union and North America produced more than $80 \%$ of the world's pork. The high demand for pig meat is usually influenced by growing population. For instance, the population eats a lot of pig meat because developing countries have become wealthier (Gentry et al. 2002). Food and Agriculture Organization (FAO, 2013) statistics indicated that the world pig numbers are increasing in most regions, with China accounting for over $50 \%$ of the world's pig population. A growing pig population is unavoidable because it is an obvious benefit to the growing human population and at the same time this means increasing piggery waste (Imbeah, 1998).

Table 1: Meat amount and percentage consumed in the world, 2012.

\begin{tabular}{|l|l|l|}
\hline Meat & $\begin{array}{l}\text { Meat consumed } \\
\text { (mmt) }\end{array}$ & $\begin{array}{l}\text { Percentage } \\
\text { of Meat (\%) }\end{array}$ \\
\hline Porcine (pork) & 110.8 & 37.4 \\
\hline Avian (poultry) & 104.5 & 35.3 \\
\hline Bovine & 66.8 & 22.6 \\
\hline Ovine & 13.9 & 4.7 \\
\hline $\begin{array}{l}\text { Total common } \\
\text { meats }\end{array}$ & 296 & 100 \\
\hline
\end{tabular}

Source: FAO, Food Outlook, 2013

Pork production was based on an extensive system or grazing 100 years ago, but currently most of the developed countries utilize the industrialized systems for most pig and pork production (Aerts et al. 2006). Furthermore, industrialized models of pork production is now recognized and practiced by the developing countries (Aerts, et al. 2006). Therefore, a new world view of pork production intends to adopt the Asian and European/American models of pig production (McGlone. 2013). The world population of pigs runs into billions today. For instance, in USA alone, one farmer keeps between
4000 and 5000 sows, with more than ten million pigs slaughtered annually (Bruno et al. 2008). Nevertheless, there is a considerable high demand of pork over the years, and therefore, the continuous growth is expected through the increasing number of pigs per farm (Iregbu et al. 2014). For example, in Nigeria, the local Government Area of Ogun state is known to be the largest producer of pigs in Black Africa with a total of 3000 farmers, more than 2000 attendants as well as 22 cooperative societies (Bakare, 2007).

\section{Piggery Waste Production}

One of the most important causative agents of environmental pollution in most parts of the world is said to be piggery waste (Sanchez et al. 1995). Manure is made of the combination faeces and urine with the ratio of $60 \%$ faeces and $40 \%$ urine ( $\mathrm{Vu}$ et al. 2007). There are three kinds of manure: slurry, liquid manure and solid manure. Slurry is a combination of urine, faeces and water; mean while solid manure is composed of faeces and litter scraped from the floor; whereas liquid manure is characterized by collectively joined urine, faeces remaining from scraping and cleaning water (Vu et al. 2007). Manure quantity is determined by the amount of feed the animal received. The quantity increases as pigs grow from piglets to slaughter pig weight (American Society of Agricultural Engineers standards, (ASAE, 2005). The amount of feed pigs received determines the total amount of organic matter excreted. The oxygen demand measures the energy content of manure, and this content increases slightly as finisher pigs reach maturity. Most of the manure organic matter is found in the faeces (ASAE, 2005). Plant nutrients is one of the manure characteristics categories. The values given in Table 2 represent the mass of the total nutrients excreted by the animal. These values are responsible for the area required to spread material when it is applied to agricultural land and pasture (ASAE, 2005).

Table 2: Daily Manure production as excreted.

\begin{tabular}{|l|c|c|c|c|c|c|c|c|c|}
\hline Animal Production Group & $\begin{array}{c}\text { Total } \\
\text { Solids }\end{array}$ & $\begin{array}{c}\text { Volatile } \\
\text { Solids }\end{array}$ & COD & N & P & K & $\begin{array}{c}\text { Total } \\
\text { Moisture }\end{array}$ & Moisture \\
\hline \multicolumn{7}{|c|}{ Kg/day/animal } \\
\hline Piglets 12.5 kg & 4.8 & 4.01 & 4.4 & 0.41 & 0.068 & 0.16 & 48 & 90 \\
\hline Grower/finisher 70 kg & 5.6 & 4.5 & 4.7 & 4.7 & 0.76 & 2.03 & 560 & 90 \\
\hline Gestating sow 200 kg & 0.5 & 0.45 & 0.45 & 0.032 & 0.009 & 0.022 & 11 & 90 \\
\hline Lactating sow 192 kg & 1.14 & 1.05 & 1.09 & 0.086 & 0.025 & 0.054 & 25 & 90 \\
\hline Boar 200 kg & 0.38 & 0.34 & 0.27 & 0.028 & 0.011 & 0.018 & 8.4 & 90 \\
\hline
\end{tabular}

COD = chemical oxygen demand (Source: American Society of Agricultural Engineers standards, (ASAE), 2005) 
Manure characteristics after storage and/or treatment of manures are better estimated by site-specific manure samples or, when farm specific information is not available. Excreted piggery waste must be stored and applied to agricultural land in such way that contamination of adjacent water, air and crops is reduced (Topp et al. 2009)

\section{Environmental impact of pig waste}

\section{Water pollution}

Animal production such as pig production causes serious water pollution through runoff and leaching of minerals from the soil as well as by disposing wastes into water courses directly. There is an accumulation of manure nutrients which are in excess of crop uptake and these nutrients eventually saturate soils. The nutrients are finally lost during saturation to either ground or surface waters (Martinez et al. 2009). The nutrients which are usually considered as very important in agriculture are phosphorus and nitrogen since they have a huge potential to cause water pollution (EEC, 1991). Another problem with the manure nutrients involves potassium, in which any application of manure based on plant uptake of phosphorus will usually lead to application of potassium (Beline et al. 2004). Many fish species are prone to free ammonia toxicity as a result of greater effect on water systems. For example, salmon is very sensitive to ammonia because it can only be affected by as little as $5 \mathrm{mg} / \mathrm{L}$ of ammonia (Martinez et al. 2009).

\section{Soil pollution}

There is an accumulation of macronutrients such as nitrogen, phosphorus and potassium as well as heavy metals such as cooper and zinc as a result of repeated applications of manure on the soil, above crop requirements. This situation does have an effect on animal health through grazing and crop feeding (Lopez Alonso et al. 2000). The interaction between soil, water and air fractions has a major effect on the nutrients overloaded soils. Air pollution is the outcome of complicated processes such as nitrification /denitrification and the breakdown as well as transformation of organic matter in the soils whereas water pollution occurs mostly through the leaching of nutrients applied in excess of plant uptake (Martinez et al. 2009) as shown in figure 1 below). Soils have a significant influence on the retention, transformation and release of gaseous or soluble compounds. For instance, in the situation of methane, soils may act as a sink through oxidation processes (Martinez et al. 2009).

\section{Air pollution}

Pain (1999) reported that animal production particularly piggery enterprise has a greater contribution to the atmospheric pollution as compared to poultry enterprise. Some research work by (Hartung and Phillips 1994) had indicated that over one hundred gaseous compounds within air found in the livestock housing are released into the atmosphere through ventilation systems. The odourous substances from those gases and particularly ammonia have been major problems from an environmental perspective. Most of the gases coming from animal husbandry occur as a result of freshly deposited faeces and urine through the activities of microbes.

\section{Emissions of ammonia}

Ammonia (NH3) volatilization is one of the major pathways of nitrogen $(\mathrm{N})$ loss from agricultural systems. It is usually formed in the soils from biological degradation of organic compounds and from ammonium (NH4) yielding synthetic and organic fertilizers (Beusen et al., 2008). Manure from farm animals was the principal source of ammonia and their emissions were damaging the environment through soil acidification and eutrophication (ECETOC, 1994). The loss of ammonia to the atmosphere occurs from housing, manure storage and application of manure to the land. Ammonia emissions of roughly $50 \%$ of swine production nature comes from the shelter and the slurry storage, while the other 50\% is emitted from land application (Martinez et al., 2009). Ammonia emissions are influenced by several important factors such as the concentration of ammonia nitrogen in the slurry, the emitting surface, the $\mathrm{pH}$ of the slurry, the air velocity over the slurry and the slurry temperature (Van der Peet-Schwering et al. 1999). Ammonia is a health risk to animal and man in animal houses due to the fact that long-term exposure to $\mathrm{NH} 3$ combined with dust can cause severe lung diseases (Seedorf and Hartung, 1999). Moreover, animal performance is decreased by high concentration of ammonia. Currently, the annual global use of synthetic nitrogen fertilizers is about $80 \mathrm{Tg}$ ( $\mathrm{Tg}=$ teragram; $1 \mathrm{Tg}=1012$ $\mathrm{g}$ ), even larger amount of animal manure $\mathrm{N}$ is produced in livestock production systems. It was stated that the use of $\mathrm{N}$ fertilizer and production of animal wastes are expected to increase in the coming decades, mostly in developing countries (Bruisma, 2003).

\section{Dust and other particles}

Dust is generally considered as a contaminant which may affect both farmer and animals ' respiratory system even though it was not reported as a major environmental issue inside animal houses (Copeland, 2006; Anderson et al. 2003). Poultry shelters were reported to have greatest concentration of airborne 


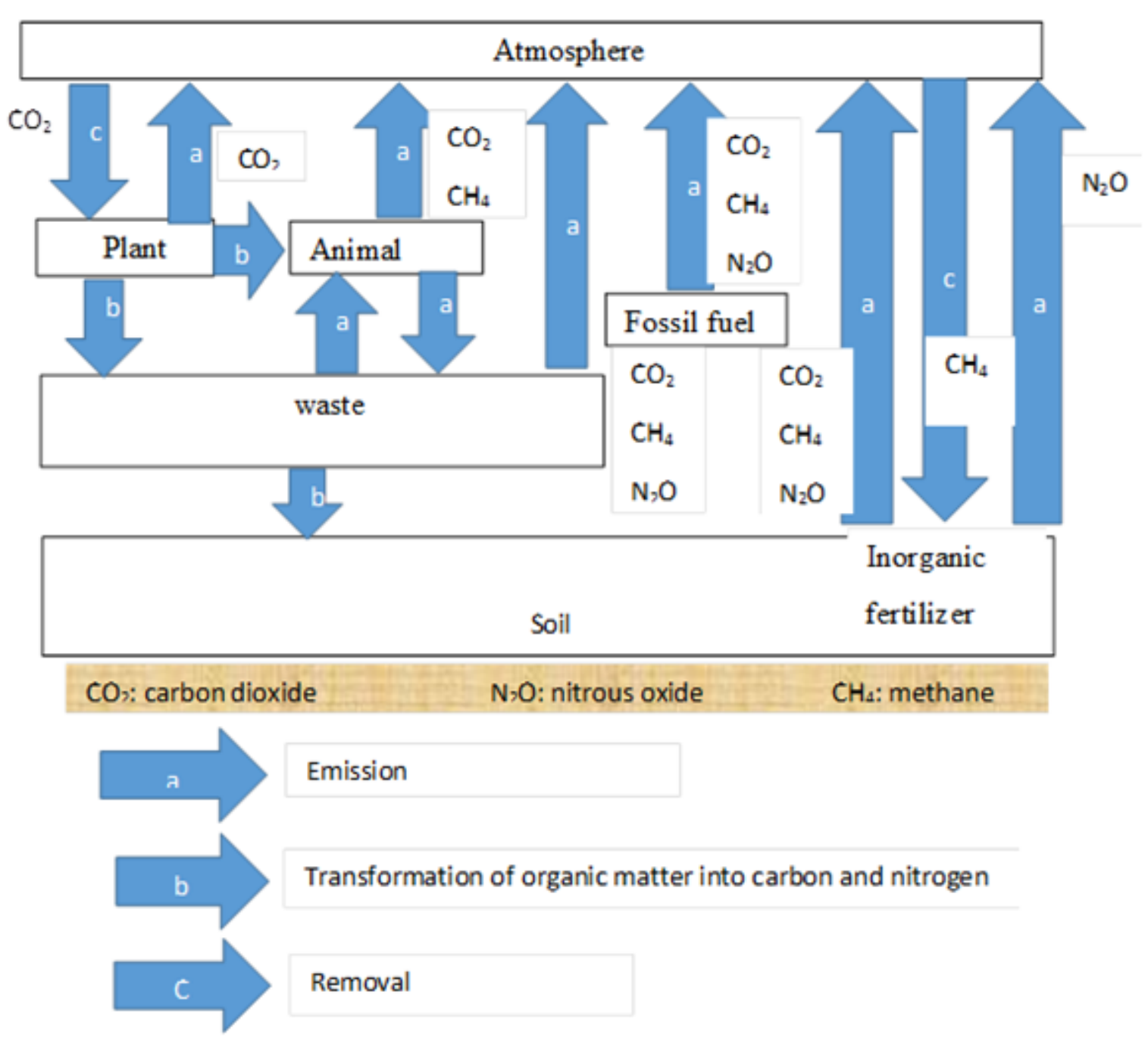

Fig. 1. Main pathways of sources and sinks of greenhouse gases associated with agriculture.

Table 3: Bio-aerosols concentration in animal houses

\begin{tabular}{|l|l|l|l|}
\hline $\begin{array}{l}\text { Bio-aerosols } \\
\text { components }\end{array}$ & $\begin{array}{l}\text { Cattle } \\
\text { house }\end{array}$ & $\begin{array}{l}\text { Pig } \\
\text { house }\end{array}$ & $\begin{array}{l}\text { Poultry } \\
\text { house }\end{array}$ \\
\hline Inhalable dust $\left(\mathrm{mg} / \mathrm{m}^{3}\right)$ & 0.4 & 2.2 & 3.6 \\
\hline $\begin{array}{l}\text { Respirable dust } \\
\left(\mathrm{mg} / \mathrm{m}^{3}\right)\end{array}$ & 0.1 & 0.2 & 0.4 \\
\hline $\left.\begin{array}{l}\text { Ihalable endotoxin } \\
(\text { EU/m }\end{array}\right)$ & 140 & 670 & 2000 \\
\hline $\left.\begin{array}{l}\text { Respirable endotoxin } \\
(\text { EU/m }\end{array}\right)$ & 10 & 70 & 210 \\
\hline Bacteria $\left(\log \mathrm{cfu}^{3} / \mathrm{m}^{3}\right)$ & 4.3 & 5.1 & 6.4 \\
\hline Fungi $\left(\log \mathrm{cfu} / \mathrm{m}^{3}\right)$ & 3.8 & 3.7 & 4.01 \\
\hline
\end{tabular}

Source: Takai and Pederson, 2002

dust, bacteria, fungi and endotoxins but high values are also found in piggery shelters. Majority of the adverse health effects such as infectious and noninfectious diseases occurred as a result of exposures to bio-aerosols components found in animal shelters (Martinez et al. 2009). The allergic reactions of the respiratory system which may become chronic, can be induced by endotoxins because they are very harmful. An overview of the different bio-aerosols components found in animal shelters is outlined in Table 3.

\section{Waste disposal}

\section{Sale of manure}

The way the management and disposal of pig waste is carried out differs from one place to another or from one country to another depending on the size of the farm and the level of technology being used at a particular farm (Iregbu et al. 2014). For example, in Northern Vietnam the middlemen are engaged in the buying and collection of manure, however they are only allowed to stop at the farm gate to buy manure because farmers were afraid that middlemen might spread infections from farm to farm (Colson and 
Boutonnet. 2006). In some areas of Vietnam, most farmers sell about $20-40 \%$ of total manure produced whereas $6 \%$ of the manure was given away to other farmers for free. The bulk of manure was not sold due to the fact that sellers and buyers were not able to meet because of either lack of established markets for manure or the cost chemical fertilizers is reasonably low and easy to use ( $\mathrm{Vu}$ et al. 2007). Moreover, it was noted that transport of manure from farms to other places is regarded as uneasy task and that pig manure transport in one village has gradually disappeared due to bad smell (Colson and Boutonnet. 2006).

\section{Use of manure for growing of crops}

The adoption of better management methods which concurrently improve production effectively, would eventually benefit the animal operations. An efficient waste storage and collection system is required before land disposal (Martinez et al. 2009). For instance, the European and North American farms have already put in place equipment and technologies that simplify the operations such as mixers and separators that reduce blockage problems and facilitate transportation (Martinez et al. 2009). Application of swine manure to crop land is one of the most obvious methods of recycling plant nutrients. Plant nutrients are removed from the soil in the harvested product fed to the animals and returned to the soil as manure. The availability of plant nutrients from swine manure depends on the composition of the manure and on other factors such as management practices and soil characteristics (Choudhary et al.1996). Pig manure is not really a waste product but it's a valuable plant nutrient resource with the added benefit of improving soil quality. However, it has to be managed properly since it can produce negative environmental impact because of the complex nature of the material (Bailey and Buckley, 1998). Therefore, land application is generally the most economical and environmentally acceptable means of disposal. Nevertheless, if pig manure is applied more than necessary then some of its components such as nitrogen, phosphorus, soluble salts and micro-nutrients can cause environmental pollution (Bailey and Buckley, 1998). In the past, the most important source of plant nutrients in crop production was farmyard manure, but unfortunately the significance of manure has decreased because of frequent use of chemical fertilizers (Phuong et al. 2006). Moreover, it was reported that in Vietnamese provinces pig manure is not commonly used for fertilization because it culturally considered to be hot or not suitable to fertilize all crops (Dan et al. 2004). The disposal of manure with effluent water through cemented drainage gutters is the most popular waste management system identified. The waste enters into sectioned covered sewage pits where they undergo aerobic, anaerobic decomposition and later evacuated to the crop farms (Iregbu et al. 2014). The cleaning up and disposal of manure from pig production wastewater is said to be one of the nation's major environmental challenges particularly in Nigeria. For example, pig waste in the western countries is handled through flushing into anaerobic lagoons from where the wastewater may be applied to crop fields (Hunt and Vanotti, 2001).

\section{Biogas production}

Bio-waste that includes animal manure produces biogas which is a degradable material from industries, agriculture, forestry and households normally dumped into landfill sites (Iregbu et al. 2014). Gases are produced by the landfill sites from buried waste undergoing anaerobic digestion. These gases are recognized as renewable energy sources despite landfill disposal being considered unsustainable (Iregbu et al. 2014). Yadava and Hesse (1981) mentioned that landfill gas contains about $50 \%$ methane which can be burned either directly for heat or to produce electricity for public use as depicted in Table 4. In other research work by $\mathrm{Vu}$ et al. (2007), it was reported that in Asian countries such as China and Vietnam biogas produced is mostly utilized for household cooking, heating water and cooking pig feed. Therefore, the appropriate amounts corresponding to manure from 20-40 pigs which are needed due to the time used for cooking food and feed is approximately 12-15 hours per day (Chinh et al. 2002).

Table 4: Composition of biogas from a mixture of biodegradable materials.

\begin{tabular}{|l|l|l|}
\hline Components & Symbol & Percentage \\
\hline Methane & $\mathrm{CH} 4$ & 50 to 70 \\
\hline Carbon-dioxide & $\mathrm{CO} 2$ & 30 to 40 \\
\hline Hydrogen & $\mathrm{H} 2$ & 5 to 10 \\
\hline Nitrogen & $\mathrm{N} 2$ & 1 to 2 \\
\hline Water vapour & $\mathrm{H} 2 \mathrm{O}$ & 0.3 \\
\hline Hydrogen sulphide & $\mathrm{H} 2 \mathrm{~S}$ & Traces \\
\hline
\end{tabular}

Source: Yadava and Hesse, 1981

Concrete bio-digesters are used in Asian countries mainly of Chinese design with a capacity of $16 \mathrm{~m} 3$ on average, ranging from $10 \mathrm{~m} 3$ to $30 \mathrm{~m} 3$ (Chinh et al. 2002; Emonet-Denand et al. 2006). In the unheated biogas digesters slurry digestion was pschrophilic in winter and mesophilic in summertime (Vu et al. 2007). The spread of pathogens and noxious odour emissions can be decreased by manure fermentation in biogas digesters. However, a larger part of the manure is treated with a short 
retention time at a low temperature in the biogas digester, with subsequent discharge of treated slurry into rivers or lakes ( $\mathrm{Vu}$ et al. 2007). The landfill gas escapes to the atmosphere if it is not harvested and this is not good due to the fact that methane is a greenhouse gas with more effect on global warming than even carbon dioxide (GWPAL, 2007). Therefore, global warming potentiality will be decreased by a factor of 23 if harvesting and burning of landfill gas (methane) is regularly carried out for provision of energy for heat and power.

\section{Use of waste in fish production}

A research study by $\mathrm{Vu}$ et al. (2007) reported that integrated pig and fish production farms had mutually benefitted each other in terms of pig waste disposal and utilization. All of the pig manure produced in the farm was used to fertilize fishponds. Liquid manure from cleaning pigs was directly channeled into fishponds and solid manure was either added to the ponds without treatment or composted for a week before being used in fishponds (Vu et al. 2007). Transportation costs to the field was reduced by discharging wastewater used for cleaning pigs into the fishponds. Nevertheless, most of the fishponds in Vietnam are connected to rivers or other water sources, in order to ensure that the actual manure proportion retained for fish production will be at a safe level (Vu et al. 2007). Some experienced farmers from surveyed reports revealed that fish in ponds fertilized with pig manure grew better than fish in ponds treated with ruminant manure due to the fact that pig manure has a higher nitrogen content than ruminant manure (Mikolasek et al. 2006). Approximately $20 \%$ of pig farmers involved in research work showed that they kept pigs mostly for using their manure for fish production because fish production in many instances yielded a better and higher price (Mikolasek et al. 2006).

\section{Legislation on pig manure management}

A total of 34 countries were involved in the global survey exercise, and it was revealed that 30 countries have national policies related to manure management. The map in Figure 2 shows the responding countries with and without manure related policies. Malawi, Senegal and Malaysia were exceptional, in which only the Ministry of Agriculture is involved, policies are often defined by the respective Ministries of Agriculture and of Environment (Teenstra et al. 2014). The involvement of the Ministries of Energy and of Public Health in defining manure policy is also not uncommon. Even though soil degradation and low crop productivity are quite common in many of the surveyed countries, broader environmental goals such as achieving methane emissions reductions and meeting renewable energy targets, or lowering of energy costs at farm level were found to be key drivers of manure (or manure related) policies (Teenstra et al. 2014). It is not a common thing for the policies to promote holistic approaches to manure management or emphasize the value of manure as a fertilizer and supplier of organic matter. Furthermore, several policies only target specific elements of manure management such as manure storage, application and disposal. A key observation of the respondents is the lack of coherence between the total set of rules (Figure 2). This phenomenon was found to occur especially in countries where multiple ministries were involved in the policy design regarding manure. Overall, legislation is often not complementary and sometimes even contradictive and does not always fit with common farm practices. Figure 2 shows that only Vietnam and a few West African countries appear to have a coherent set of rules for manure management.

In some real situations, having legislation on manure management is one thing, but enforcing it may cause another whole issue for debate. Generally, enforcement of manure policies is regarded as being weak (Figure 3) mostly in situations where multiple ministries are involved, there is often a lack of coordination between the ministries and their enforcing bodies resulting in unclear procedures and penalties (Teenstra et al. 2014). Enforcement of regulation was found to vary across the surveyed countries; respondents from China, Viet Nam, Malaysia, Panama, Ecuador and Chile indicated well -coordinated law enforcement. It should be noted that the absence of manure policy does not indicate the absence of good manure management practices (Teenstra et al. 2014). For example, despite having no manure policy, farmers in El Salvador have applied manure to coffee for several years. Moreover, pig and poultry manure is used in organic crop production, and a number of the larger livestock and poultry farms with bio-digesters use the digestate in crop production.

\section{Piggery waste treatment systems}

\section{Aerobic digestion}

One of the well-recognized technologies for the treatment of sludge produced by wastewater treatment plants is the auto-thermal thermophilic aerobic digestion (ATAD). The temperature rises over $50.80 \mathrm{C}$ in this type reactor because of the conservation of a part of the heat produced by the aerobic metabolism of the microorganisms that eat the organic material inside the sludge (Juteau, 2006). ATAD is very important in this process because it is 


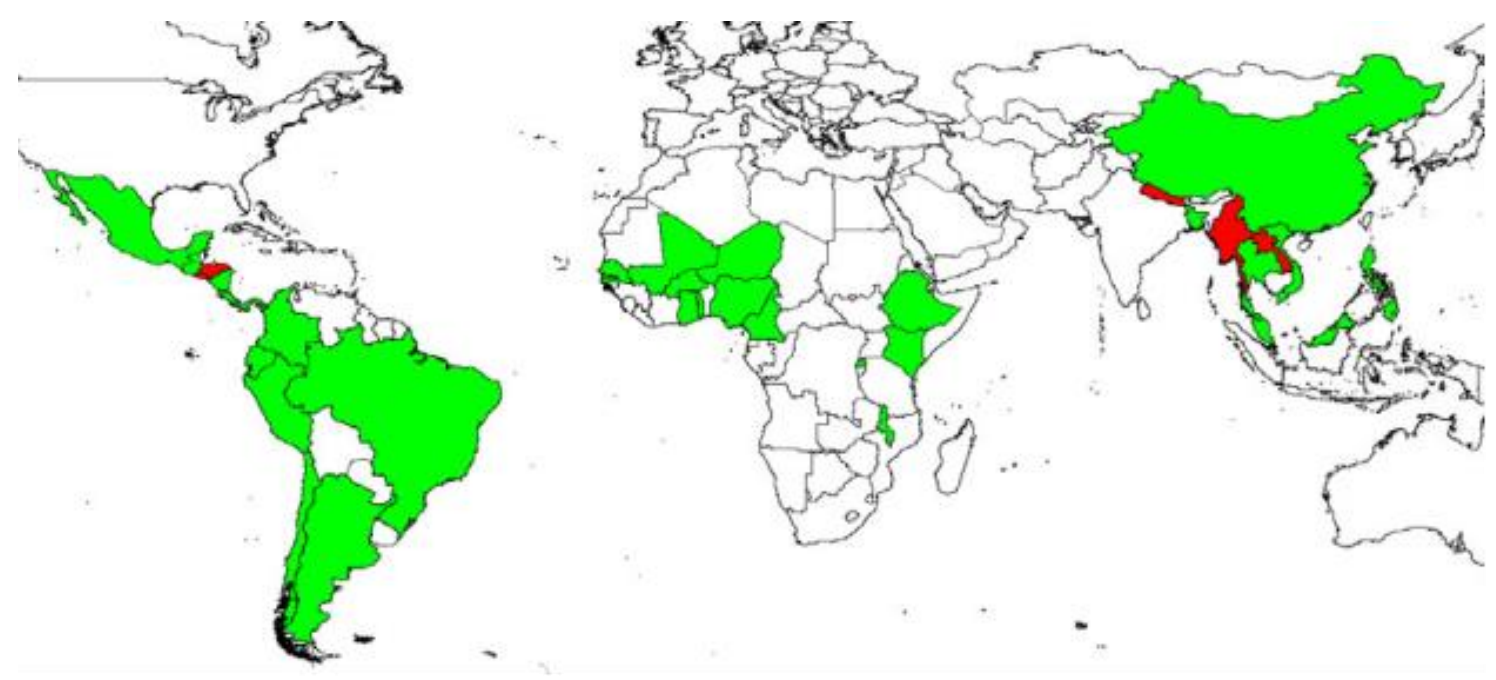

Fig. 2: Surveyed countries with (green) and without (red) manure management related policies (Source: Teenstra et al. 2014).

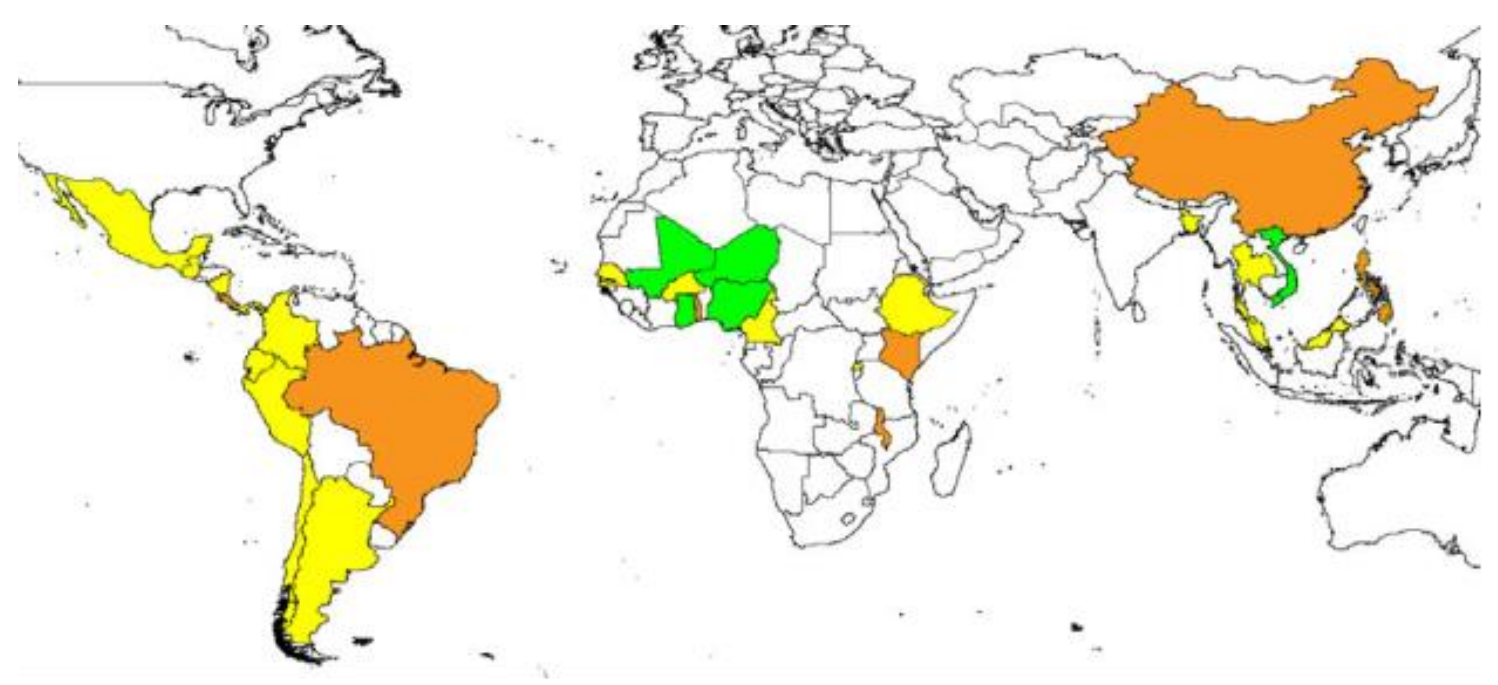

Fig. 3: Level of coherence in the manure legislation (Source: Teenstra et al. 2014).

Green = very good: very complementary; holistically approached national policy in which relevant ministries have adapted their departmental policies to each other's responsibilities resulting in an integral manure management policy (taking into account i.e. human health, different pollutions, use of natural resources etc.)

Yellow = moderate: some contradicts, i.e. environmental policy in line with proper manure management, but no connection with human health policies; or overall no conflicting policies but may be still some policy gaps remain to be solved.

Orange $=$ bad/none: contradictive; no holistically approached national policy, policy often based on single issues by responsible ministries, with as a result conflicting legislation.

effectively killing pathogenic organisms. Aerobic thermophilic digestion has been considered as a process which could be utilized for the treatment of livestock wastes in the form of liquid particularly with pig manure. Moreover, the reported benefits of this process include the simplicity of the process, its robustness, a higher reaction rate, the conservation of nitrogen and possibility of heat recovery in addition to the pathogen killing effect (Juteau, 2006). However, full scale aerobic thermophilic plants for liquid manure are scarce and majority of them have been set for experimental purposes. These plants can be found in Germany, United Kingdom, Scandinavia, Czechoslovakia, United States and Canada (Martens et al. 1998; Burton and Turner, 2003). The experimental confirmation had already been done in 
Germany in the 1960s and since then, self-heating up to the thermophilic range has been shown for various organic wastes including liquid manure (Martens et al. 1998; Burton and Turner, 2003; Juteau et al. 2004). Self-heating usually needed a minimal quantity of organic material for its sustainability, but an absolute value is not easy to establish. The pasteurization effect of the auto-thermal thermophilic process came as result of $\mathrm{pH}$ and temperature rising during the treatment (Martens et al. 1998). The pathogens which have been indicated to be destroyed quickly in this type of treatment include bacteria (coliforms, salmonella, campylobacter, clostrium perfringens), viruses (swine vascular disease, Foot and Mouth Disease), protozoa (cryptosporidium), and parasites (ascaris and taenia eggs) (Martens et al. 1998).

\section{Anaerobic digestion}

In this type of process, large volume is required for the conventional anaerobic digestion and the process encouraged an investigation of alternatives using the same principle of anaerobic digestion but with retention of biomass (Sanchez et al. 1995). Anaerobic packed bed (APB) and up-flow anaerobic sludge bed (UASB) were the most promising methods for anaerobic digestion. The anaerobic packed bed reactor is characterized by the use of support which is mainly to raise the contact area between the microorganisms and substrate. A biofilm is formed, and long solids retention time is observed as the microorganisms remained in the reactor usually attached to the support. The microorganisms remained in the reactor in a sludge bed located at the bottom in the up-flow anaerobic sludge bed process. The influent enters at the bottom of the reactor and passes through the sludge bed up to the top where baffles are located to prevent the solids from being washed out and to separate the biogas from the effluent. The results were obtained when the support is adequately colonized by biofilm as well as when sludge granulation was obtained (Lettinga et al. 1992). Anaerobic fixed bed and up-flow sludge bed reactors with various wastes including piggery waste were compared. The researchers concluded that the up-flow sludge bed reactor could sustain high loading rates and high rates of methane production as compared with the fixed bed reactor. It was observed that chemical oxygen demand removal efficiencies were slightly greater for the sludge bed reactor. Nevertheless, the sludge bed reactor was more sensitive to changes in temperature, waste composition and flow differences (Sanchez et al. 1995).

\section{Composting}

This is an aerobic, biological process that uses naturally occurring micro-organisms to biodegradable organic matter into a humus-like product (Georgacakis et al. 1996). In this process, the pathogens are destroyed, and nitrogen is converted from unstable ammonia to stable organic forms, reducing the volume of waste and eventually improves the nature of the waste. Animal waste is made easier to be handled and transported by compositing and eventually allowed for higher application rates due to more stable, slow release and nature of nitrogen in compost (Sequi, 1996). There are several factors which influence the composting process, such as temperature, oxygen supply, moisture content, $\mathrm{pH}$, Carbon: Nitrogen ratio, particle size and degree of compaction (Stentiford, 1996). Composting is regarded as an environmentally acceptable method of waste treatment (Georgacakis et al. 1996). Pig manure has to be separated so that it can remain with solids of up to $79 \%$ moisture for successful composting process. The upper limit for moisture content of substrates is $65 \%$ or slight above for appropriate compositing exercise as long as there is enough air in the compost to satisfy the oxygen needs of the microorganisms (Stentiford, 1996). Manure solids separation decreases the nutrient load and the potential of the wastewater to pollute waterways prior to pond treatment of effluent or direct land application. Recycling of wastewater can be done for flushing more manure after solid separation, while decreasing the amount of water used and disposed of (Van Horn et al. 1994). Furthermore, the suitable bulking agents are combined with separated manure solids in an appropriate ratio and composited accordingly. The low-moisture bulking agents include materials such as sawdust, straw, peanut shells, rice hull and chicken litter (Georgacakis et al. 1996). The bulking agents are responsible for absorbing excess moisture resulting in an accelerated and odorless process. The efficiency of composting process is determined by the temperature which dependent on the aeration rate (Lau et al. 1992). A maximum temperature ranging from $550 \mathrm{C}$ to $650 \mathrm{C}$ is adequate to kill pathogens, however mesophilic temperatures of 450 to $550 \mathrm{C}$ should be retained for maximum biodegradation (Stentiford, 1996). The amount of oxygen available to the microorganisms in the compost influences the temperature attained by a compost pile, and thus the aerobic nature of the composting process. The compost is aerated through turning the pile, forced aeration of the pile using pumps or passive aeration where air can flow through the pile (Georgacakis et al. 1996). On the other hand, too little porosity leads to anaerobic conditions and odour generation, and therefore, percentage of air-filled pore space of 
composting piles should be in the range of $35-50 \%$ (Bernal et al. 2009).

\section{Conclusion}

There is a need to promote waste management methods that would protect the environment and also allow the recycling of manure. The early separation of liquids from solids in livestock houses may be of great benefit because it reduces gaseous emissions in the buildings, and it generates liquid and solids that can be processed separately with new techniques. There is need to integrate possible stronger policies on environmental protection such as the necessity to include new emerging pollutants such as antibiotics, endocrine disrupters and antibiotic resistant pathogens.

\section{Acknowledgments}

The authors express sincere thanks and gratitude to Professor Essau Waugh and Dr Molebeledi Mareko for helpful suggestions and comments.

\section{References}

Aerts S., Lips D., Spencer S., Decuypere E. and De Tavernier J.A. (2006). A new framework for the assessment of animal welfare: Integrating existing knowledge from a practical ethics perspective. J. Agr. Environ. Ethics 19: 67-76.

American Society of Agricultural Engineers standards, (ASAE D384.2), (2005). Manure Production and Characteristics. ASAE-The Society for engineering in agricultural, food, and biological systems 2950 Niles Rd., St. Joseph, MI 49085-9659, USA ph.269-429-0300. Available at http://large.stanford.edu/publications/power/refe rences/docs/ASAEStandard.pdf (Accessed: May 2017).

Anderson N., Strader R.and Davidson C. (2003). Airbone reduced nitrogen: ammonia emissions from agriculture and other sources. Environment International 29: 2777-2786.

Bailey L. and Buckley K. (1998). Land application of pig manure agronomic and environmental considerations, the Canadian perspective. Presented at the Hems workshop Toronto, Ontario, April 27-28.

Bakare M. (2007). Pig farm with a difference. The news 28(13): 67-69.

Batool S.A. and Ch M.N. (2009). Municipal solid waste management in Lahore city district, Pakistan. Waste Management 29: 1971-1981.

Beline F., Daumer M.L. and Guiziou F. (2004). Biological aerobic treatment of pig slurry in France: nutrients removal efficiency and separation performances. Transactions of the
ASAE 47(3): 857-864.

Bernal M.P., Alburquerque J.A. and Moral R. (2009). Composting of animal manures and chemical criteria for compost maturity assessment: A review. Bioresource Technology 100: 5444-5453.

Beusen A.H., Bouwman A.F., Heuberger P.S., Van Drecht G. and Van Der Hoek K.W. (2008). Bottom-up uncertainty estimates of global ammonia emissions from global agricultural production systems. Atmospheric environment 42: 6067-6077.

Bouwman A.F. and Booij H. (1998). Global use and trade of feedstuffs and consequences for the nitrogen cycle. Nutr. Cycl. Agroecosyst 52: 261267.

Bruinsma J.E. (2003). World agriculture: towards 2015/2030. An FAO perspective. Earthscan, London, 432pp.

Burton C.H. and Turner C. (2003). Manure management: Treatment strategies for sustainable agriculture, $2^{\text {nd }}$ edition. Siloe research Institute Siloe, Bedford, UK.

Chau L.H. (1998). Biodigester effluent versus manure, from pigs or cattle, as fertilizer for duckweed (Lemna spp). Livestock Research for Rural development 10(3). Available at http://www.cipav.org.co/llrrd/ (Accessed: July 2018).

Chinh B.V., Ly L.V., Tao N.H. and Phuc G.N. (2002). Biogas technology transfer in small scale in Northern provinces of Vietnam. Proc. Biodigester workshop. Available at http://www.mekarn.org/procbiod/chinh.htm (Accessed November 2017).

Choudhary M., Bailey L.D. and Grant C.A. (1996). Review of the use of swine manure in crop production: effects on yield and composition and on soil and water quality. Waste management and research 14: 581-595.

Colson C. and Boutonnet J.P. (2006). Economic appraisal of animal manure considered as a commodity. In: Porphyre, V., Coi, N.Q. (Eds), Pig production development, Animal waste management and environment protection: A case study in Thai Binh province, Northern Vietnam. PRISE publications France, pp. 163-179.

Copeland C. (2006). Air quality issues and animal agriculture: a primer. CRS report for congress, R132948, Congressional Research service.

Dan T.T., Hoa T.A., Hung L.Q., Tri B.M., Hoa H.T., Hien L.T. and Tri N.N. (2004). Area wideintegration of specialized crop and livestock activities in Vietnam. Project report pp. 24-27.

De N.V., Murrell K.D., Cong L.D., Cam P.D., Chau L.V.,Toan N.D. and Dalsgaard A. (2003). The food-borne trematode zoonoses of Vietnam. 
Southeast Asian J. Trop. Med. Public health 34: 12-34.

EEC/91/676, O.J. NL 375. (1991). Protection of waters against pollution caused by nitrates from agricultural sources.

Emonet-Denand V., Porphyre V., Ly N.T., Bien D.H. and Paillat J.M. (2006). Pig farmers, their internal use of pig manure and their evolution change patterns. In: Porphyre, V., Coi, N.Q. (Eds), Pig production development, Animal waste management and environment protection: A case study in Thai Binh province, Northern Vietnam. PRISE publications France, pp. 83106.

European Centre for EcoToxicology and Toxicology of Chemicals (ECETOC), (1994). Ammonia emissions to air in Western Europe. Tech. Rep No. 62, ECETOC, Brussels, Belgium.

FAO, (2013). Food outlook. Available at http://www.fao.org/docrep/012/ak341e/ak341e0 9 (Accessed on April 2017).

Gentry J., McGlone J., Miller M. and Blanton J. (2002). Diverse birth and rearing environment effects on pig growth and meat quality. J. Anim. Sci. 80: 1707-1715

Georgackis D., Tsavdaris A., Bakouli J. and Symeonidis S. (1996). Composting solid swine manure and lignite mixture with selected plant residues. Bioresource Technology 56: 195-200.

Gerber P., Chilonda P., Franceschini G. and Menzi H. (2005). Geographical determinants and environmental implications of livestock production intensification in Asia. Biores. Technol 96: 263-276.

Global Warming Potentials and Atmospheric Lifetimes (GWPAL). 2007. Non- $\mathrm{CO}_{2}$ gas economic analysis and inventory. Available at $\underline{\mathrm{http}: / / w w w . e p a . g o v / n o n C O} 2$ /econinv/table.html, USA Environmental Protection Agency (USEPA) (Accessed on August 2017).

Hartung G.J. and Phillips V.R. (1994). Control of gaseous emissions from livestock buildings and manure stores. Journal of agricultural Engineering Research 57: 173-189.

Hunt P.G. and Vanotti M.B. (2001). Coping with swine manure. USDA-ARS-Coastal plains soil water and plant resources centre Florence, S.C.

Imbeah M. (1998). Composting piggery waste: a review. Bioresource Technology 63: 197-203.

Iregbu G.U., Kubkomawa I.H., Okoli C.G., Ogundu E.C., Uchegbu M.C. and Okoli I.C. (2014). Environmental concerns of pig waste production and its potentials as biofuel source. J.Ani.and vet.sciences 1(3): 17-24.

Jarvis S.C., Stockdale E.A., Shepherd M.A. and Powlson D.S. (1996). Nitrogen mineralization in temperate agricultural soils: processes and measurement. Adv.Agron 57: 187-235.

Juteau P. (2006). Review of the use aerobic thermophilic bioprocesses for the treatment of swine waste. Livestock Science 102: 187-196.

Juteau P., Tremblay D., Ould-Moulaye C.B., Bisaillon J.G. and Beaudet, R. (2004). Swine waste treatment by self-heating aerobic thermophilic bioreactors. Water Res 38: 539546.

Lau A.K., Lo K.V., Liao P.H. and Yu J.C. (1992). Aeration experiments for swine waste composting. Bioresource Technology 41: 145152.

Lettinga G., Rinzema A. and Hulshoff P. (1992). Possibilities and potentials of anaerobic wastewater treatment with emphasis on the UASB system. Proceedings $3^{\text {rd }}$ workshop of working Group on Biogas production technologies Braunschweig, Germany, 5-7 May, 73-90.

Lopez Alonso M., Benedito J.L., Miranda M., Castillo C., Hernandez J. and Shore, R.F. (2000). The effect of pig farming on copper and zinc accumulation in cattle in Galicia (Northwestern Spain). The veterinary journal 160: 259-266.

Martens W., Fink A., Philip W., Weber W., Winter D. and Bo hm R. (1998). Inactivation of viral and bacterial pathogens in large scale slurry treatment plants. In: Martinez, J., Maudet, M. N., (Eds.), Proc. RAMIRAN 98: 8th International conference on management strategies for organic waste use in agriculture Rennes, France, pp. 529-539.

Martinez J., Dabert P., Barrington S. and Burton, C. (2009). Livestock waste treatment systems for environment quality, food safety and sustainability. Bioresource Technology 100: 5527-5536.

McGlone J.J. (2013). The future of pork production in the world: towards sustainable, welfare positive systems. Animals 3: 401-415.

Mikolasek O., Guerin G., Lopez A., Khuyen T.D., Huy P.T. and Dien N.T. (2006). Local fish farming practices and a typology of farms based on organic matter intake management. In: Porphyre, V., Coi, N.Q. (Eds), Pig production development, Animal waste management and environment protection: A case study in Thai Binh province, Northern Vietnam. PRISE publications France, pp. 107-125.

Organization for economic Cooperation and Development (OCED), (2001). Environmental indicators for agriculture. Methods and Results vol 3, Paris, France.

Pain B.F. (1999). Gaseous pollutants from organic waste use in agriculture. In: Martinez, J. and 
Maudet, M.N. (Eds), Proceedings of the $8^{\text {th }}$ International Conference of the FAO-Network on recycling agricultural, municipal and industrial residues in agriculture (Ramiran 98) 26-29 May. Cemegref-FAO Editions, Rennes, France.

Phuong N.H., Tuan V.D. and Toan T.D. (2006). Farmer's practices organic and inorganic fertilization on crops, trees and vegetables. In: Porphyre, V., Coi, N.Q. (Eds), Pig production development, Animal waste management and environment protection: A case study in Thai Binh province, Northern Vietnam. PRISE publications France, pp. 145-162.

Sanchez E.P., Monroy O., Canizares R.O., Travieso L. and Ramos A. (1995). A Preliminary study of pig waste treatment by an Upflow sludge bed anaerobic reactor and a packed bed anaerobic reactor. J. Agric. Eng. Res. 62: 71-76.

Seedorf J. and Hartung J. (1999). Survey of ammonia concentrations in livestock buildings. Journal of Agricultural Science, Cambridge, 133: 433-437.

Seo, S., Aramaki, T., Hwang, Y., Hanaki, K., 2004. Environmental impact of solid waste treatment methods in Korea. Journal of Environmental Engineering Div., ASCE 130 (1): 81-89.

Sequi P. (1996). The role of composting in sustainable agriculture. In The Science of Composting Part 1, eds M.de Bertoldi, P. Sequi, B. Lemmes and T. Papi, pp. 23-29. Blackie, Glasgow.

Sharholy M., Ahmad K., Mahmood G. and Trivedi R.C. (2008). Municipal solid waste management in Indian cities - a review. Waste Management 28(2): 459-467.

Stentiford E.I. (1996). Composting control: principles and practice. In The Science of Composting Part 1, eds M. de Bertoldi, P. Sequi, B. Lemmes and T. Papi, pp. 29-59. Blackie, Glasgow.

Takai H. and Pederson S. (2002). Livestock related fine dust -composition, structure and flows. Landbauforschung volkenrode 235: 139-144.

Teenstra E., Vellinga T., Aektasaeng N., Amatayakul W., Ndambi A., Pelster D., Germer, L. Jenet A., Opio C. and Andeweg K. (2014). Global assessment of manure management policies and practices. Livestock Research Wageningen UR.

Topp E., Scott A., lapen D.R., Lyautey E. and Duriez P. (2009). Livestock waste treatment systems for reducing environmental exposure to hazardous enteric pathogens: some considerations, Bioresource Technology 100: 5395-5398.

Van der Peet-Schwering C.M., Aarnink A.J., Rom H.B. and Dourmad J.Y. (1999). Ammonia emissions from pig houses in the Netherlands, Denmark and France. Livestock Production
Science 58: 265-269.

Van Horn, N. H., Wilkie, A. C., Powers, W. J., Nordstedt, R. A. (1994). Components of dairy manure management systems. Journal of Dairy Science 77(7): 2008-2030.

Vu T.K.V., Tran M.T. and Dang T.T.S. (2007). A survey of manure management on pig farms in northern Vietnam. Livestock Science 112: 288297.

Yadava L.S. and Hesse P.R. (1981). Development and use of biogas technology. Available at https://scholar.google.com/scholar?hl=en\&as_sd $\mathrm{t}=0,5 \&$ as_vis $=1 \& \mathrm{q}=$ Development + and + use + of + biogas+technology+by+yadav+and+hesse.

(Accessed on April 2017). 